\title{
STATISTICAL ANALYSIS OF Cu AND Zn CONCENTRATIONS IN BLACK TRUMPETS (CRATERELLUS CORNUCOPIOIDE). ECOLOGICAL RISK ASSESSMENT
}

\author{
Lilko Dospatliev ${ }^{1} \&$ Miroslava Ivanova ${ }^{2}$ \\ ${ }^{1}$ Department of Pharmacology, Animal Physiology and Physiological Chemistry, Faculty of \\ Veterinary Medicine, Trakia University \\ Student campus, Stara Zagora 6000, Bulgaria, e-mail: Ikd@abv.bg \\ ${ }^{2}$ Department of Informatics and Mathematics, Faculty of Economics, Trakia University \\ Student campus, Stara Zagora 6000, Bulgaria, e-mail: mivanova@uni-sz.bg
}

\begin{abstract}
The aim of this study was to determine copper $(\mathrm{Cu})$ and zinc $(\mathrm{Zn})$ concentrations in wild edible black trumpet mushrooms (Craterellus cornucopioides) from the Batak mountain, Bulgaria. The preparation of samples was made by means of dry ashing and dissolution in $3 \mathrm{M} \mathrm{HCl}$. An atomic absorption spectrometer "AAnalyst 800 with graphite furnace HGA" Company "Perkin Elmer was used for determination of $\mathrm{Cu}$ and $\mathrm{Zn}$ content in the mushroom samples. Wavelengths: $\mathrm{Cu}-324.8 \mathrm{~nm}$ and $\mathrm{Zn}-213.9 \mathrm{~nm}$ was used. The total Cu content in mushroom samples varied from $3.436 \mathrm{mg} \mathrm{kg}^{-1}$ to $5.962 \mathrm{mg} \mathrm{kg}^{-1}$, and the total Zn content of samples ranged between $9.636 \mathrm{mg} \mathrm{kg}^{-1}$ and $13.981 \mathrm{mg} \mathrm{kg}^{-1}$. According to WHO criteria, all measured $\mathrm{Cu}$ and $\mathrm{Zn}$ concentrations were under the permissible limits. SPSS (Statistical Package for Social Science) program for Windows was used for statistical data processing. The differences between the values of parameters are characterised by the range, dispersion, standard deviation and coefficient of variation

The ecological risk was calculated confirming that the Batak mountain is an ecologically pure region. Keywords: Atomic absorption spectrometer, mushroom Craterellus cornucopioides, Batak mountain, $\mathrm{Cu}, \mathrm{Zn}$, Ecological risk.
\end{abstract}

\section{INTRODUCTION}

Variability in the chemical composition of mushrooms within a species is greater than that of plants, much more so than within cultivars of a crop. Each individual fruit body can result from the cross-breeding of different hyphae and so presents a distinct genotype [1-7]. Contents of a trace element in a mushroom species therefore vary widely, even by as much as 1 order of magnitude. Mushroom species, but most probably not genus, level of substrate composition, and local pollution with trace elements are the principal factors affecting trace element level in fruit bodies. The lifetime of most fruit bodies is usually only $10-14$ days. Thus the role of fruit body age and size is of less importance owing to the limited proportion of contaminants originating from atmospheric depositions. However, this role may increase in some wood-growing species that have a longer lifespan than is usual in aboveground species [16-18,23-25,28,29]. Mushrooms not only accumulate elements from underlying substrate but also from host trees depending on the specificity of species. Elements detrimental to humans originate from both natural sources and anthropogenic activities. Motor transport delivers significant amounts of both gaseous pollutants and selected elements, which generally negatively influence human health and contribute to changes in climate (EPA) [23-25,32]. In Bulgaria, apart from the sale of cultivated mushrooms in shops, wild growing mushroom species are frequently sold along roadsides and in street markets. 


\section{IRTILV $\vee$}

Ipplied Researleches in Technics, Technologies and Bductition

Journal of the Faculty of Technics and Technologies, Trakia University https://sites.google.com/a/trakia-uni.bg/artte/

The aim of this study was to determine copper $(\mathrm{Cu})$ and zinc $(\mathrm{Zn})$ concentrations in wild edible black trumpet mushrooms (Craterellus cornucopioides) from the Batak mountain, Bulgaria and calculated the ecological risk.

\section{METHODS}

\subsection{Atomic absorption spectrophotometer apparatus and analysis conditions}

For the elemental analysis, a Perkin-Elmer Analyst 800 atomic absorption spectrometer with deuterium background corrector was used in this study.

The operating parameters for working elements by graphite furnace were set as recommended by the application note. Atomic absorption spectrophotometer (AAS) graphite furnace operating parameters and temperature programme are given in Table 1, respectively.

Table 1. Instrumental analytical conditions of element analyses

\begin{tabular}{|l|c|c|c|c|c|}
\hline AAS & $\begin{array}{c}\text { Acetylene } \\
\left(\mathrm{I} \mathrm{min}^{-1}\right)\end{array}$ & $\begin{array}{c}\text { Air } \\
\left(\mathrm{I} \mathrm{min}^{-1}\right)\end{array}$ & $\begin{array}{c}\text { Wavelength } \\
(\mathrm{nm})\end{array}$ & $\begin{array}{c}\text { Slit width } \\
(\mathrm{nm})\end{array}$ & $\begin{array}{c}\text { Lamp current } \\
(\mathrm{mA})\end{array}$ \\
\hline $\mathrm{Cu}$ & 2.0 & 17.0 & 324.8 & 0.7 & 15 \\
\hline $\mathrm{Zn}$ & 2.0 & 17.0 & 213.9 & 0.7 & 15 \\
\hline
\end{tabular}

\subsection{Reagents}

Reagents are qualified "AR" (pa Merck \& Fluka). The starting standard solutions for AAS determination of $\mathrm{Zn}$ and $\mathrm{Cu}$ at concentrations of $1000 \mathrm{mg} \mathrm{l}^{-1}$ were supplied by Merck, Darmstadt Germany.

All chemicals were at least of analytical reagent grade. Water was de-ionized in a Milli-Q system (Millipore, Bedford, MA, USA) to a resistivity of $18.2 \mathrm{MV} \mathrm{cm}$.

All plastic and glassware were cleaned by soaking in diluted $\mathrm{HNO}_{3}(1 / 9, \mathrm{v} / \mathrm{v})$ and were rinsed with distilled water prior to use.

\subsection{Samples}

One hundred and fifty mushroom samples were collected in 2014 and 2015 from the Batak mountain by the authors themselves.

The samples were prepared for the experiment in a standard way; they were dried at $65^{\circ} \mathrm{C}$ in a fan oven and stored in dark polyethylene bottles.

\subsection{Sample preparation}

Dry ashing

Procedure for dry ashing at $525{ }^{\circ} \mathrm{C}$ in a muffle furnace, following Bulgarian standard 11708 93 , was used. Samples $(0.5 \mathrm{~g})$ were weighed in $50 \mathrm{ml}$ glass beakers, charged on a hot plate with stepwise increasing temperature up to $350{ }^{\circ} \mathrm{C}$ for 4 hours and finally ashed in a muffle furnace at $525{ }^{\circ} \mathrm{C}$ for 1 hour. After cooling ashes were dissolved in $20 \mathrm{ml}$ of in $3 \mathrm{M} \mathrm{HCl}$. 


\section{IRTIIE}

Ipplied Researleches in Technics, Technologies ind Educiation

Journal of the Faculty of Technics and Technologies, Trakia University https://sites.google.com/a/trakia-uni.bg/artte/

\subsection{Assessment of potential ecological risk}

The assessment of potential ecological risk is performed by the following formulas:

$R_{l}=\Sigma E_{r}{ }^{i}(1)$

$E_{r}{ }^{i}=T_{r}{ }^{i} C_{f}^{i}(2)$

$C_{f}{ }^{i}=C_{0}{ }^{i} / C_{n}{ }^{i}(3)$

The potential ecological risk index $\left(R_{l}\right)$ was introduced to assess the degree of heavy metal pollution in mushrooms, according to the toxicity of heavy metals and the response of the environment. $R_{l}$ is calculated as the sum of all risk factors for heavy metals in mushrooms, $E_{r}^{i}$ is the monomial potential ecological risk factor, $T_{r}{ }^{i}$ is the toxic-response factor for a given substance, which accounts for the toxic requirement and the sensitivity requirement, as shown in Table 2. $C_{f}{ }^{i}$ is the contamination factor, $C_{0}{ }^{i}$ is the concentration of metals in the mushrooms, and $C_{n}{ }^{i}$ is a reference value for metals (Table 2).

Table 2. Reference values $\left(C_{n}{ }^{\prime}\right)$ and toxicity coefficients $\left(T_{r}{ }^{\prime}\right)$ of heavy metals in mushrooms

\begin{tabular}{|l|c|c|}
\hline Heavy metals & $\mathrm{Cu}$ & $\mathrm{Zn}$ \\
\hline$C_{n}{ }^{i}\left(\mathrm{mg} \mathrm{kg}^{-1}\right)$ & 10 & 40 \\
\hline$T_{r}{ }^{i}$ & 5 & 1 \\
\hline
\end{tabular}

Based on the reference values for these elements, the adjusted evaluation criteria for the ecological risk index $R_{l}$ are listed in Table 3.

Table 3. Terminology used to describe the risk factor $E_{r}{ }^{i}$ and $R_{l}$

\begin{tabular}{|l|l|l|l|}
\hline$E_{r}{ }^{i}$ & $\begin{array}{l}\text { Potential ecological } \\
\text { risk for single regulator }\end{array}$ & $R_{l}$ & $\begin{array}{l}\text { Ecological risk } \\
\text { for all factors }\end{array}$ \\
\hline$E_{r}{ }^{i}<20$ & Low & $R_{l}<47$ & Low \\
\hline $20 \leq E_{r}{ }^{i}<40$ & Moderate & $47 \leq R_{l}<94$ & Moderate \\
\hline $40 \leq E_{r}{ }^{\prime}<80$ & Considerable & $94 \leq R_{l}<188$ & Considerable \\
\hline $80 \leq E_{r}{ }^{\prime}<160$ & High & $R_{l} \geq 188$ & Very high \\
\hline$E_{r}{ }^{i} \geq 160$ & Very high & & \\
\hline
\end{tabular}

\subsection{Statistical}

SPSS (Statistical Package for Social Science) program for Windows was used for statistical data processing.

We calculated the average value and the median being central features of the empirical distribution function. In order to measure the asymmetric distribution and excess, we used coefficients of asymmetry and excess. The differences between the individual indicators were characterized by the statistical dispersion, the variance, the standard deviation and the coefficient of variation, representing a measure of statistical dispersion. The greater the statistical dispersion, the higher the coefficient of variation.

The differences between the values of parameters are characterised by the range, dispersion, standard deviation and coefficient of variation. 


\section{ARTTIE $Y$}

Ipplied Resseirlohes in Technics, Technologies and Bductation

Journal of the Faculty of Technics and Technologies, Trakia University https://sites.google.com/a/trakia-uni.bg/artte/

\section{EXPERIMENTAL}

Table 4. Descriptive analysis of the results for $\mathrm{Cu}$ and $\mathrm{Zn}$ concentrations in the mushrooms Craterellus cornucopioides

\begin{tabular}{|l|c|c|}
\hline & $\mathrm{Cu}$ & $\mathrm{Zn}$ \\
\hline Mean & 4.579 & 11.429 \\
\hline Standard Error & 0.259 & 0.417 \\
\hline Median & 4.431 & 11.427 \\
\hline Standard Deviation & 1.002 & 1.616 \\
\hline Sample Variance & 1.004 & 2.610 \\
\hline Kurtosis & -1.692 & -1.443 \\
\hline Skewness & 0.232 & 0.257 \\
\hline Range & 2.526 & 4.343 \\
\hline Minimum & 3.436 & 9.638 \\
\hline Maximum & 5.962 & 13.981 \\
\hline Sum & 68.688 & 171.437 \\
\hline Count & 15.000 & 15.000 \\
\hline Confidence Level (95,0\%) & 0.555 & 0.895 \\
\hline
\end{tabular}

Table 5. The values potential ecological risk index $\left(R_{l}\right)$ of heavy metals in mushrooms Craterellus cornucopioides

\begin{tabular}{|l|c|c|c|c|}
\hline & $C_{0}{ }^{i}, \mathrm{mg} \mathrm{kg}^{-1}$ & $C_{f}{ }^{i}$ & $E_{r}{ }^{i}$ & $R_{l}$ \\
\cline { 1 - 4 } $\mathrm{Cu}$ & 4.579 & 0.458 & 2.290 & \multirow{2}{*}{2.575} \\
\hline $\mathrm{Zn}$ & 11.4 .29 & 0.286 & 0.286 & \\
\hline
\end{tabular}

\section{RESULTS}

The total $\mathrm{Cu}$ content in mushroom samples varied from $3.436 \mathrm{mg} \mathrm{kg}^{-1}$ to $5.962 \mathrm{mg} \mathrm{kg}^{-1}$ (Table 4). According to WHO criteria, all measured $\mathrm{Cu}$ concentrations were under the permissible limits.

The arithmetic mean is $4.5792 \mathrm{mg} \mathrm{kg}^{-1}$, which value is greater than the median, ie there is a positive right asymmetry. So speaks the asymmetry coefficient (0.232). Coefficient of excess is negative (-1.692). Normal scattering values of copper to average leads to normal values of standard deviation and coefficient of variation, which are respectively 1.002 and 1.004 .

Copper is the third-most abundant trace element in human body and small amount of $\mathrm{Cu}$ is found in the human body $(50-120 \mathrm{mg})$, but it plays a critical role like vitamin in a variety of biochemical processes [20-22,26-28,30-33]. Copper forms part of at least 13 different enzymes, and its presence is needed for each if they are to function properly. It is known that Cu may be toxic to both humans and animals when its concentration exceeds the safe limits. Copper concentrations, accumulated in mushroom species, are usually $100-300 \mu \mathrm{g} \mathrm{g}^{-1}$, which is not considered a health risk [30-33]. These levels are above the WHO permissible limits in foods, which is $40 \mu \mathrm{g} \mathrm{g}^{-1}[19,37,38]$. Copper contents of mushroom samples in the literature have been reported to be in the ranges: $4.71-51.0 \mu \mathrm{g} \mathrm{g}^{-1}, 10.3-145 \mu \mathrm{g} \mathrm{g}^{-1}, 12.0-$ $181.0 \mu \mathrm{g} \mathrm{g}^{-1}, 13.4-50.6 \mu \mathrm{g} \mathrm{g}^{-1}, 24.1-86.2 \mu \mathrm{g} \mathrm{g}^{-1}, 10.6-144.2 \mu \mathrm{g} \mathrm{g}^{-1}$, and $15.0-73.0 \mu \mathrm{g} \mathrm{g}^{-1}$ (Sesli et al., 2008), respectively [1-7]. The Cu results of our study were in lower with those found in the literature [20-22, 26-28, 30-35]. 


\section{ARTTE $Y$}

Ipplied Resseirlohes in Technics, Technologies and Bductation

Journal of the Faculty of Technics and Technologies, Trakia University https://sites.google.com/a/trakia-uni.bg/artte/

The total $\mathrm{Zn}$ content in mushroom samples varied from $9.638 \mathrm{mg} \mathrm{kg}^{-1}$ to $13.981 \mathrm{mg} \mathrm{kg}^{-1}$ (Table 4). According to WHO criteria, all measured $\mathrm{Zn}$ concentrations were under the permissible limits [19].

The arithmetic mean is $11.429 \mathrm{mg} \mathrm{kg}^{-1}$, which value is greater than the median, ie there is a positive right asymmetry. So talk and positive asymmetry coefficient $(0.257)$. Coefficient of excess is negative (-1.443). Normal scattering values of zinc to average leads to normal values of standard deviation and coefficient of variation, which are respectively 1.616 and 2.610 (Table 4). The WHO permissible limit of $\mathrm{Zn}$ in foods is $60.0 \mu \mathrm{g} \mathrm{g}^{-1}$. The values for $\mathrm{Zn}$ in some investigated mushroom samples were above the WHO's values. Zinc concentrations of mushroom samples in the literature have been reported to be in the ranges: $29.3-158.0 \mu \mathrm{g}$ $\mathrm{g}^{-1}, 33.5-89.5 \mu \mathrm{g} \mathrm{g}^{-1}, 40.3-64.4 \mu \mathrm{g} \mathrm{g}{ }^{-1}, 45.2-173.8 \mu \mathrm{g} \mathrm{g}^{-1}$, and $43.5-205.0 \mu \mathrm{g} \mathrm{g}^{-1}, 42.9-$ $94.3 \mu \mathrm{g} \mathrm{g}^{-1}$, respectively. The $\mathrm{Zn}$ results of our study were in lower with those found in the literature [8-15].

In Table 5 are presented calculated values of $C_{f}{ }^{i}, E_{r}{ }^{i}$ and $R_{l}$. It is seen that the values of $E_{r}{ }^{i}$ and the two elements are much smaller than 40 , it means that Potential ecological risk for single regulator is Low. Also, it is seen that $R_{I}=2.575$, which means that Ecological risk for all factors is also Low.

\section{CONCLUSIONS}

From the resulting value of $R_{l}$ can say that locality Batak mauntain is ecologically clean area and very suitable for collecting wild edible mushrooms that we can use in our daily menu.

\section{REFERENCES}

[1] Árvay J., Tomáš J., Hauptvogl M., Kopernická M., Kováčik A., Bajčan D. \& Massányi P. (2014) Contamination of wild-grown ediblemushrooms by heavy metals in a former mercury-mining area. Journal of Environmental Science and Health B, Vol. 49, (2014), pp. 815-827.

[2] Ayaz F.A., Torun H., Colak A., Sesli E., Millson M. \& Glew R.H. (2011). Macroand microelement contents of fruiting bodies of wild-edible mushrooms growing in the east Black Sea region of Turkey. Food and Nutrition Sciences, Vol. 2, (2011), pp. 53-59.

[3] Borovička J. \& Řanda Z. (2007). Distribution of iron, cobalt, zinc and selenium in macrofungi. Mycological Progress, Vol. 6, (2007), pp. 249-259.

[4] Breś W., Golcz A., Komosa A., Kozik E. \& Tyksiński W. (2009). Żywienie roślin ogrodniczych. The breeding of garden plants. University of Life Sciences Publishing, Poznań, (2009).

[5] Cayır A., Coskun M. \& Coskun M. (2010). The heavy metal content of wild edible mushroom samples collected in Canakkale Province, Turkey. Biological Trace Element Research, Vol. 134, (2010), pp. 212-219.

[6] Chen X. H., Zhou H.B. \& Qiu G.Z. (2009). Analysis of several heavy metals in wild edible mushrooms from regions of China. Bulletin of Environmental Contamination and Toxicology, Vol. 83, (2009), pp. 280-285.

[7] Chojnacka A. \& Falandysz J. (2007). Mineral composition of yellow-cracking bolete (Xerocomus subtomentosus) (L.). Quelet. Bromat Chemistry Toksykol, Vol. 40, (2007), pp. 337-340.

[8] Chojnacka A., Jarzyńska G., Lewandowska M., Nnorom I. C. \& Falandysz J. (2013). Trace elements in Yellow-cracking Bolete [Xerocomus subtomentosus (L.) Quel.] collected at the same site over three years. Fresen Environ Bull, Vol. 22, (2013), pp. 2707-2712. 


\section{ARTTE $Y$ Y}

Ipplied Resseirlohes in Technics, Technologies and Bductation

Journal of the Faculty of Technics and Technologies, Trakia University https://sites.google.com/a/trakia-uni.bg/artte/

[9] Chudzyński K., Jarzyńska G. \& Falandysz J. (2013). Cadmium, lead and some other trace elements in Larch Bolete mushrooms (Suilllus grevillei) (Klotzch) Sing., collected from the same site over two years. Food Additives \& Contaminants B, Vol. 6, (2013), pp. 249-253.

[10] Cocchia L., Vescovia L., Petrinid L. E. \& Petrini O. (2006). Heavy metals in edible mushrooms in Italy. Food Chemistry, Vol. 98, (2006), pp. 277-284.

[11] Cuny D., van Haluwyn C. \& Pesch R. (2001). Biomonitoring of trace elements in air and soil compartments along the major motorway in France. Water, Air, \& Soil Pollution, Vol. 125, (2001), pp. 273-289.

[12] Demirbas A. (2000). Accumulation of heavy metals in some edible mushrooms from Turkey. Food Chemistry, Vol. 68, (2000), pp. 415-419.

[13] Diez V. A. \& Alvarez A. (2001). Compositional and nutritional studies on two wild edible mushrooms from northwest Spain. Food Chemistry, Vol. 75, (2001), pp. 417-422.

[14] Durkan N., Ugulu I., Unver M.C., Dogan Y. \& Baslar S. (2011). Concentrations of trace elements aluminum, boron, cobalt and tin in various wild edible mushroom species from Buyuk Menderes River Basin of Turkey by ICP-OES. Trace Elements and Electrolytes, Vol. 28, (2011), pp. 242-248.

[15] Dursun N., Ozcan M.M., Kasik G. \& Ozturk C. (2006). Mineral contents of 34 species of edible mushrooms growing wild in Turkey. Journal of the Science of Food and Agriculture, Vol. 86, (2006), pp. 1087-1094.

[16] Falandysz J. \& Borovička J. (2013). Macro and trace mineral constituents and radionuclides in mushrooms: health benefit and risks. Applied Microbiology and Biotechnology, Vol. 97, (2013), pp. 477-501.

[17] Falandysz J., Kawano M., Swieczkowski A., Brzostowski A. \& Dadej M. (2003). Total mercury in wild-grown higher mushrooms and underlying soil from Wdzydze Landscape Park, Northern Poland. Food Chemistry, Vol. 81, (2003), pp. 21-26.

[18] Falusi B. A. \& Olanipekun E. O. (2007). Bioconcentration factors of heavy metals in tropical crab (Carcinus sp.) from River Aponwe, Ado-Ekiti, Nigeria. Journal of Applied Sciences and Environmental Management, Vol. 11, (2007), pp. 51-54.

[19] FAO/WHO (1999). Expert Committee on Food Additives, Summary and Conclusions. Fifty-third Meeting, Rome, (1999).

[20] Gençcelep H., Uzun Y., Tuncturk Y. \& Demirel K. (2009). Determination of mineral contents of wild-grown edible mushrooms. Food Chemistry, Vol. 113, (2009), pp. 10331036.

[21] Gramss G. \& Voigt K-D. (2013). Clues for regulatory processes in fungal uptake and transfer of minerals to the basidiospore. Biological Trace Element Research, Vol. 154, (2013), pp. 140-149.

[22] Gucia M., Jarzyńska G., Kojta A.K. \& Falandysz J. (2012). Temporal variability in 20 chemical elements content of Parasol Mushroom (Macrolepiota procera) collected from two sites over a few years. Journal of Environmental Science and Health B, Vol. 47, (2012), pp. 81-88.

[23] Guillamón E., Garcia-Lafuente A., Lozano M., D’Arrigo M., Rostagno M. A., Villares A. \& Martínez J. A. (2010). Edible mushrooms: role in the prevention of cardiovascular diseases. Fitoterapia, Vol. 81, (2010), pp. 715-723.

[24] Haider S., Naithani V., Barthawal J. \& Kakkar P. (2004). Heavy metalcontent in some therapeutically important medicinal plants. Bulletin of Environmental Contamination and Toxicology, Vol. 72, (2004), pp. 119-127.

[25] Huang Q., Jia Y., Wan Y., Li H. \& Jiang R. (2015). Market survey and risk assessment for trace metals in edible fungi and the substrate role in accumulation of heavy metals. Journal of Food Science, Vol. 80, (2015), pp. 1612-1618. 


\section{ARTIIE

[26] Isıldak O., Turkekul I., Elmastas M. \& Tüzen M. (2004). Analysis of heavy metals in some wild-grown edible mushrooms from the middle Black Sea region, Turkey. Food Chemistry, Vol. 86, (2004), pp. 547-552.

[27] Isıloglu M., Yılmaz F. \& Merdivan M. (2001). Concentrations of trace elements in wild edible mushrooms. Food Chemistry, Vol. 73, (2001), pp. 169-175.

[28] Kalač P. (2010). Trace element contents in European species of wild growing edible mushrooms: a review for the period 2000-2009. Food Chemistry, Vol. 122, (2010), pp. 2-15.

[29] Kalač P. \& Svoboda L. (2001). A review of trace element concentrations in edible mushrooms. Food Chemistry, Vol. 69, (2001), pp. 273-281.

[30] Kaya A. \& Bag H. (2010). Trace element contents of edible macrofungi growing in Adiayman, Turkey. Asian Journal of Chemistry, Vol. 22, (2010), pp. 1515-1521.

[31] Kojta A.K., Jarzyńska G. \& Falandysz J. (2012). Mineral composition and heavy metal accumulation capacity of Bay Bolete (Xerocomus badius) fruiting bodies collected near a former gold and copper mining area. Journal of Geochemical Exploration, Vol. 121, (2012), pp. 76-82.

[32] Künzli N., Kaiser R., Medina S., Studnicka M., Chanel O., Filliger P., Herry M., Horak F. Jr., Puybonnieux-Texier V., Quénel P., Schneider J., Seethaler R., Vergnaud J-C. \& Sommer H. (2000). Public-health impact of outdoor and traffic-related air pollution: a European assessment. Lancet, Vol. 356, (2000), pp. 795-801.

[33] Manzi P., Aguzzi A. \& Pizzoferrato L. (2001). Nutritional value of mushrooms widely consumed in Italy. Food Chemistry, Vol. 73, (2001), pp. 321-325.

[34] Mleczek M., Niedzielski P., Kalač P., Siwulski M., Rzymski P. \& Gąsecka M. (2016). Levels of platinum group elements and rare earth elements in wild mushroom species growing near a busy trunk road. Food Additives \& Contaminants A, Vol. 33, (2016), pp. 86-94.

[35] Mleczek M., Siwulski M., Mikołajczak P., Gąsecka M., Rissmann I., Goliński P. \& Sobieralski K. (2015). Differences in Cu content in selected mushroom species growing in the same unpolluted areas in Poland. Journal of Environmental Science and Health B, Vol. 50, (2015), pp. 659-666.

[36] Niedzielski P., Mleczek M., Magdziak Z., Siwulski M. \& Kozak L. (2013). Selected arsenic species: As(III), As(V) and dimethylarsenic acid (DMAA) in Xerocomus badius fruiting bodies. Food Chemistry, Vol. 141, pp. 3571-3577.

[37] Sesli E. \& Tuzen M. (1999). Levels of trace elements in the fruiting bodies of macro.ingi growing in the East Black Sea region of Turkey. Food Chemistry, Vol. 65, (1999), pp. 453-460.

[38] Sivrikaya H., Bacak L., Saracbası A., Toroglu I. \& Eroglu H. (2002). Trace elements in Pleurouts Sajor-caju cultivated on chemithermomechanical pulp for bio-bleaching. Food Chemistry, Vol, 79, No. 2, (2002), pp. 173-176. 